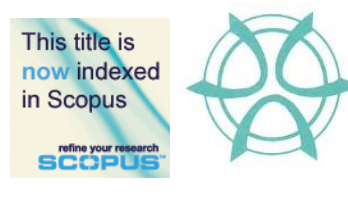

PLANNING MALAYSIA:

Journal of the Malaysian Institute of Planners

VOLUME 16 ISSUE 4 (2018), Page 188 - 198

\title{
BUILDING OPENING DESIGN CONTRIBUTING TO TRADITIONAL STREETS' WALKABILITY CHARACTER IN MELAKA HISTORIC CITY
}

\author{
Nor Haslina Ja'afar ${ }^{1}$ \& Nor Zalina Harun² \\ ${ }^{I}$ Faculty of Engineering and Built Environment \\ ${ }^{2}$ Institute of the Malay World and Civilisation \\ UNIVERSITI KEBANGSAAN MALAYSIA
}

\begin{abstract}
The street as a public space plays an essential role in representing the character of a city. Therefore, it is vital to create streets that are pedestrian friendly. However, rapid urbanisation has increased reliance on motorised modes of transport, especially in developing countries. This has created urban street environments unfriendly for walking, which diminishes the place character. This study thus aims to determine the ground-level building opening design concepts of the traditional street that promote street interaction via a case study of Jalan Tukang Besi, Jalan Tukang Emas, and Jalan Tokong in Melaka Historic City. The study applies a mixed-method approach with a survey, in-depth interviews of street users, observation, and review of historical documents to identify the character of the traditional street within the design of ground-level building opening. The findings reveal that the building opening design concept should correspond to the building function. The design concept for a commercial use building should be more transparent compared to a residential building, which is more private in character. The findings inform designers and planners on the importance of referring to our traditional street design and to apply the concepts in the design of new or existing streets, thereby preserving the local character.
\end{abstract}

Keywords: public space, traditional street, character, building opening, street design 
PLANNING MALAYSIA

Journal of the Malaysia Institute of Planners (2018)

\section{INTRODUCTION}

The image of a town or city depends on the image of its streets, i.e., if the streets are walkable and have a strong character, so do the city (Jaafar, Abdul Rahim, Abd Samad, \& Che Rahim, 2017). In urban design, the street is an essential public open space that acts as a 'link' as well as a 'place'. The 'link' refers to the street's function for movement serving a variety of users including pedestrians, cyclists, public transport, and motor vehicles. The purpose of the street as a 'link' is to save time. While the street as a 'place' refers to it as a destination: a place where people spend their time. This refers to pedestrians conducting and taking part in a variety of activities (Jones \& Boujenko, 2011; Jones \& Boujenko, 2008; Gehl, Kaefer, \& Reigstad, 2006; Gehl \& Gemzøe, 2001).

On the other hand, rapid urbanisation has also increased reliance on motorised modes of transport such as cars, especially in developing countries. In the process, many of our heritage buildings were not conserved and were replaced by new, modernist buildings that were built without considering the existing context that was rich in historical values and characters. At the same time, the construction of large buildings, such as shopping complexes, destroys the existing fine grain and texture of the street and the city. According to Gehl, (2010), the 'big-box' design of such buildings discourages ground-level interaction between people inside and outside. The blank walls create an unsafe environment due to the lack of natural surveillance while the long blank walls create unwalkable surroundings for pedestrians to mingle around. Instead, interactions take place inside the building via an indoor street design. The result is an urban street environment that is unfriendly for walking. This disruption of the existing urban form reduces the street and place character.

The explanation above portrays that it is crucial to develop place character with walkable environments by designing buildings that encourage interactions especially at the street level. To this end, this study aims to determine the design concepts of ground-level building openings that create street interactions that contribute to the traditional street character at Melaka Historic City, Malaysia.

\section{RESEARCH BACKGROUND}

There have been many works on pedestrian-friendly urban street that emphasise theories of walkability, such as Harun and Nashar (2016), Litman (2014), and Clark, Scott and Yiannakoulias (2013). Among the most prominent is Speck (2012), who lists the characteristics of interesting and walkable cities with pedestrian-friendly streets. He argues that walking needs to be safe, useful, comfortable, and attractive; each characteristic could not exist without the other. Other proponents of walkable streets such as Jacobs (1993) and Litman (2014) also emphasise that being pleasurable, prioritising pedestrians, having meaning, 
Mohd Hafiz Mohd Nor, Asmidar Alias \& Mohd Faizal Musa

Social Capital in Youth Volunteerism

eyes engaging, possessing transparency, and ensured complementary with streetscape elements are pertinent qualities.

A more localised study by Rahman, Shamsuddin and Ghani (2014), and Yap, Usman, Tahir and Abidin (2010) asserts that the street environment must have the attributes of short distance or proximity, minimal congestion, familiarity, greenery, public amenities, regularly maintained, and allowing freedom of activities. Previous studies have also measured walkability in terms of the number of lanes or high accessibility, presence of crosswalks, and density (Asfar, Mohd Yazid, \& Mohd Johari, 2015), high density development (Miyakoda, 2005), street attractiveness, and high connectivity (Litman, 2014), minimal distance to non-residential destinations and land-use mix (Handy, Xinyu, \& Mokhtarian, 2005), and connectivity, personal safety, and presence of parks and open spaces (Sallis, Frank, Saelens, \& Kraft, 2004; Maleki, Zain, \& Ismail, 2014).

\section{METHODOLOGY}

A survey of street users was conducted by distributing questionnaires to collect quantitative data while direct observation, in-depth interviews of street users, and review of documents of historical significance yielded qualitative data. All methods were applied to triangulate the building design elements that contribute towards the walkable character of the traditional streets in Melaka Historic City Centre.

Street users were randomly selected as respondents for the survey. They included shop owners, street vendors, shopkeepers, workers, shoppers, visitors, and residents. 335 respondents were selected for a 95\% confidence level and $5.5 \%$ sampling error as suggested by de Vaus (2003) and applied in Shamsuddin and Ujang (2008). The questionnaire was designed with both multiple-choice and open-ended questions, and each respondent was given 20 minutes to complete the questionnaire with a 40-minute interval between respondents.

In-depth interviews were conducted on 21 respondents in a semistructured format, in which questions were prepared in advance as a guide to ensure all variables were covered during the interview. The interviews collected the respondents' length of engagement, whether they are local, and familiarity with the place and its milieu. According to character theory, it is essential to gather information from locals or those who are familiar with the area so that the historical significance of the place as well as other factors that contribute to the place character could be identified. Audio recordings and handwritten notes were taken of the interviews. In addition, a review of historical documents such as old photo and map was also conducted to determine the area's historical significance.

The study was also conducted by observation, whereby visual analysis was applied on data recorded using digital camera and field notes to document the physical characteristics, pattern of activities, and users to understand the 
PLANNING MALAYSIA

Journal of the Malaysia Institute of Planners (2018)

milieu of the area (Zakariya, Mansor, \& Harun, 2015). The observations were conducted during weekdays and weekends except during the festive season. All data from the in-depth interviews, document review, and observation were then analysed through thematic coding using NVivo.

\section{SITE STUDY AREA}

The study applied site study as a research strategy, involving three streets as a social place that portrays the local character. Three streets at Melaka Historic City Centre were chosen, namely Jalan Tukang Emas, Jalan Tukang Besi, and Jalan Tokong, which combine to create one long street (Figure 1). Dedicated as UNESCO urban heritage, the area has the highest concentration of local inherent socio-cultural identity.

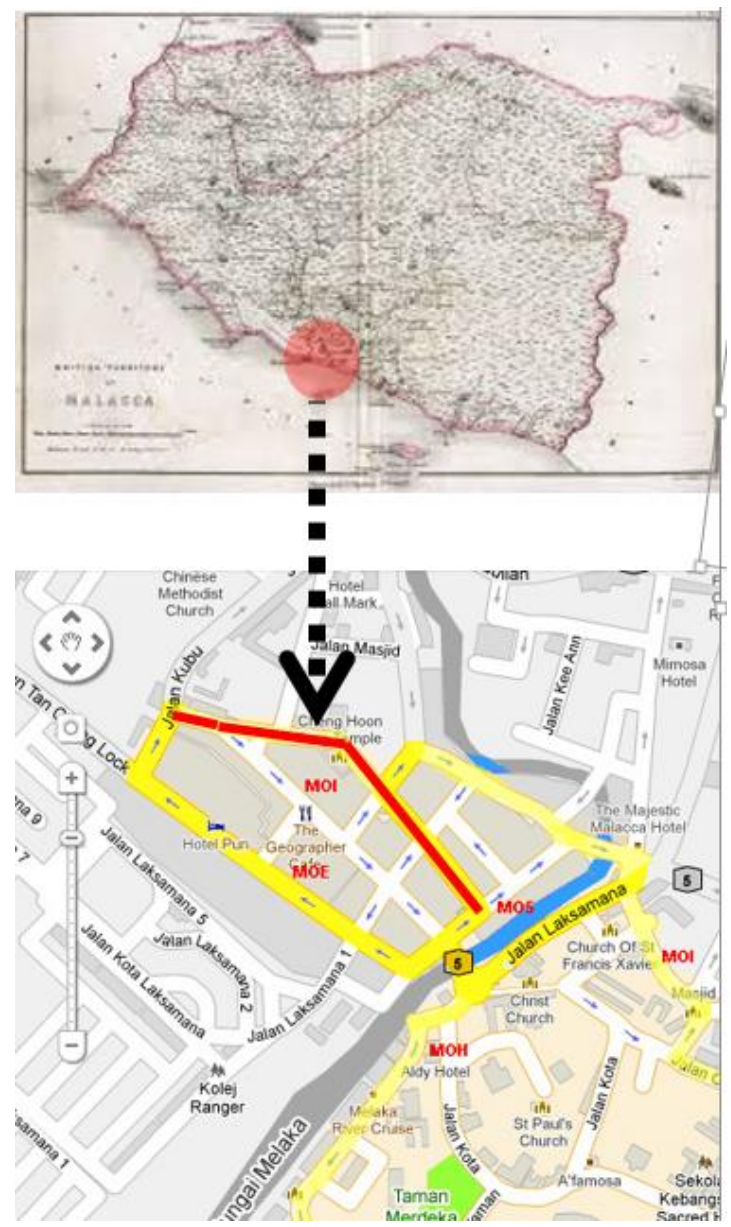

Figure 1: Location of the area of study Source: Google Map 
Mohd Hafiz Mohd Nor, Asmidar Alias \& Mohd Faizal Musa

Social Capital in Youth Volunteerism

\section{RESULTS}

The study finds that there are two types of ground-level building opening that contribute to the traditional street character in Melaka Historical City Centre, namely, commercial/civic, and residential openings. Table 1 below shows that ground-level opening was mentioned in the findings of all research methods including by all respondents $(n=21)$ interviewed.

Table 1: Types of building opening that contribute towards traditional street character

\begin{tabular}{|l|c|c|c|c|c|}
\hline \multirow{2}{*}{ Building attribute } & \multirow{2}{*}{$\begin{array}{c}\text { Survey } \\
(\mathrm{n}=330)\end{array}$} & \multicolumn{2}{|c|}{$\begin{array}{c}\text { In-depth interview } \\
\text { (street users) (n=21) }\end{array}$} & $\begin{array}{c}\text { Visual } \\
\text { survey }\end{array}$ & $\begin{array}{c}\text { Historical } \\
\text { document }\end{array}$ \\
\cline { 3 - 4 } $\begin{array}{l}\text { Commercial/civic } \\
\text { opening at ground level }\end{array}$ & $\checkmark$ & 21 & - & $\checkmark$ & $\checkmark$ \\
\hline $\begin{array}{l}\text { Residential opening at } \\
\text { ground level }\end{array}$ & $\checkmark$ & 21 & - & $\checkmark$ & $\checkmark$ \\
\hline
\end{tabular}

Source: Fieldwork, 2016

According to Alexander (1977), three types of ground-level building opening design that generate street interaction are designs that (i) use glass, (ii) use openings such as shutters, and (iii) applies a 'walking through activity' approach, with activity overflowing from the inside to the outside of the building. This study will use these types of ground level building opening design as measurement.

Historical records show that the 'walking through activity' approach to ground-level opening design is synonymous with business and commercial buildings. Merchandise overflow outside of the building into the five-foot way or the street itself. This situation is representative of Malaysia local character and image of informal activities (Shamsuddin, Sulaiman, Ja'afar, \& Noor, 2004).

Based on our observation, the 'walking through activity' approach to ground-level opening design for commercial use have remained in place until today. As shown in Figure 2, 50.1\% of the units (77 units from 151 units) of the units observed still use this kind of opening design concept. Therefore, it can be said that the 'walking through activity' character of ground-level building opening design can still be experienced until today. 
PLANNING MALAYSIA

Journal of the Malaysia Institute of Planners (2018)

\section{Concept of Ground Level Opening}

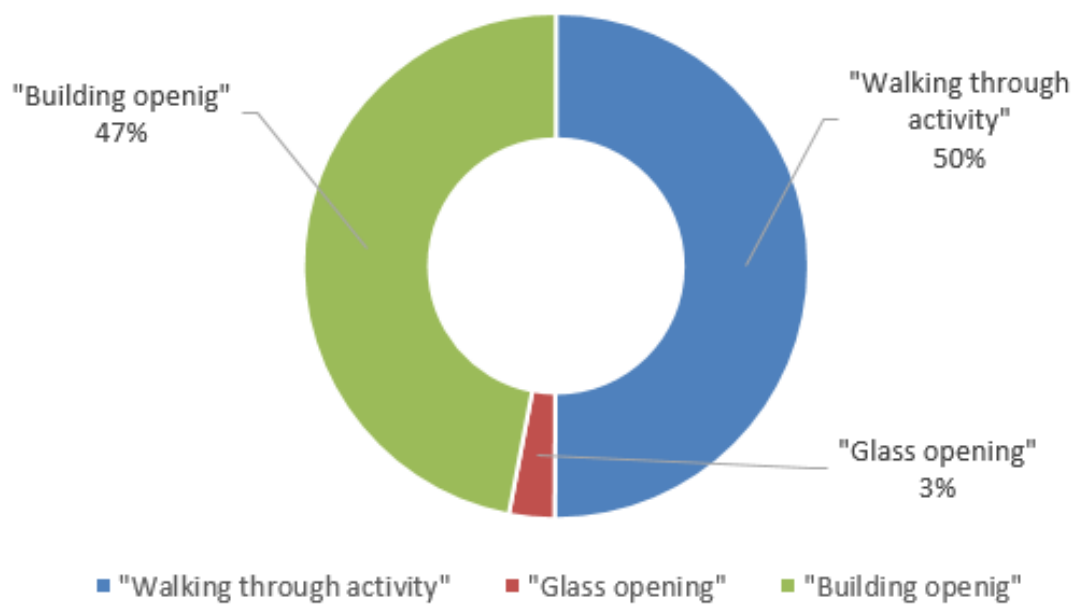

Figure 2: Pie chart: Types of ground-level building opening design according to visual survey

Source: Fieldwork, 2016

Our survey results also show that most respondents associated the diverse designs of ground-level opening with building use. As in Table 2, ground-level opening design is associated with street attractiveness (65.4\%), elements that identify a place (90\%), and recalled type of building use (72.2\%).

Table 2: Questions associated with recognising activity

\begin{tabular}{clcc}
\hline No. & Recognising activity & $\begin{array}{c}\text { Frequency } \\
\mathrm{n}=330\end{array}$ & $\%$ \\
\hline 1 & $\begin{array}{l}\text { Elements that identify building activity occurring } \\
\text { on the street } \\
\text { Building use: (activity inside and outside the } \\
\text { building) }\end{array}$ & 238 & $72.2 \%$ \\
$\quad \begin{array}{l}\text { Elements that identify a place } \\
\text { Building use (e.g., mosque) }\end{array}$ & 297 & $90.0 \%$ \\
4 & Street attractiveness: diversity of building use & 216 & $65.4 \%$ \\
\hline Reference: Fieldwork, 2016 & &
\end{tabular}

All respondents $(n=21)$ interviewed also reported recognising building use by the type of ground-level building opening. One of the respondents commented:

"I feel that the speciality of this place is that I can see clearly the types of businesses because the sale items could be seen from 
Mohd Hafiz Mohd Nor, Asmidar Alias \& Mohd Faizal Musa

Social Capital in Youth Volunteerism

outside until the five-foot way. I enjoy and feel safe and comfortable walking here." (Respondent 4)

The above quote shows that the respondent recognised the type of businesses through the display or overflow of merchandise outside of the building. The respondent also added that the diverse and transparent environments create the impression of a street that is safe, comfortable, and enjoyable to walk around.

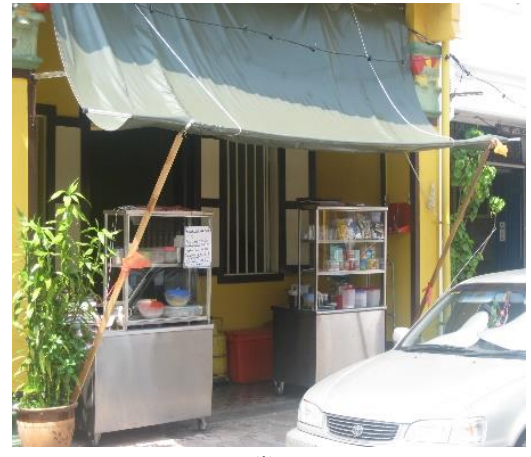

(i)

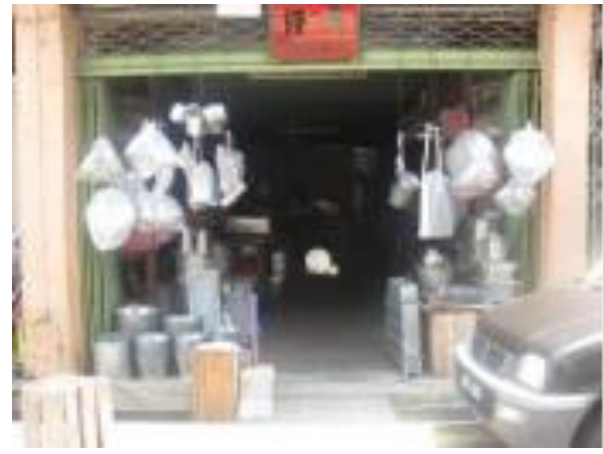

(ii)

Figure 3: Overflow of activities from the inside to the outside of the building creates a high level of transparency.

Source: Fieldwork, 2016

Our observations also found that the 'walking through activity' groundlevel opening designs of buildings for commercial use clearly showed the types of merchandise and activities occurring inside as well as outside of the buildings. We could see the activities of buying and selling, cooking and eating, etc. The overflow of items to the five-foot way and sidewalk create a strong sense of transparency even though the opening designs of some of the shop-houses were not fully transparent. This 'walking through activity' concept was found to be applied in the study area mostly on buildings for commercial use such as restaurant, grocery and souvenir shops.

While commercial of building use such as offices, traveller's lodges, and Chinese clan association are apply the use of "building openings" and "glass opening" as their ground-level building opening design. As shown in Figure 2, $3 \%$ of the units (2 units from 151 units) observed used "glass opening' and 47\% of the units (72 units from 151 units) were using "building openings" of ground floor opening design concept. We observed that pedestrians were able to see clearly and recognise the activities of building use, as supported by interview findings where most respondents were able to identify buildings functioning as 
traveller's lodges or hotels. Added they mentioned the diversity timber door and window create a building and place uniqueness (Figure 4).

This shows that buildings for commercial use should have large openings to create a high degree of transparency. However, according to previous study, the types of ground-level opening design should also consider the kind of business and service offered.
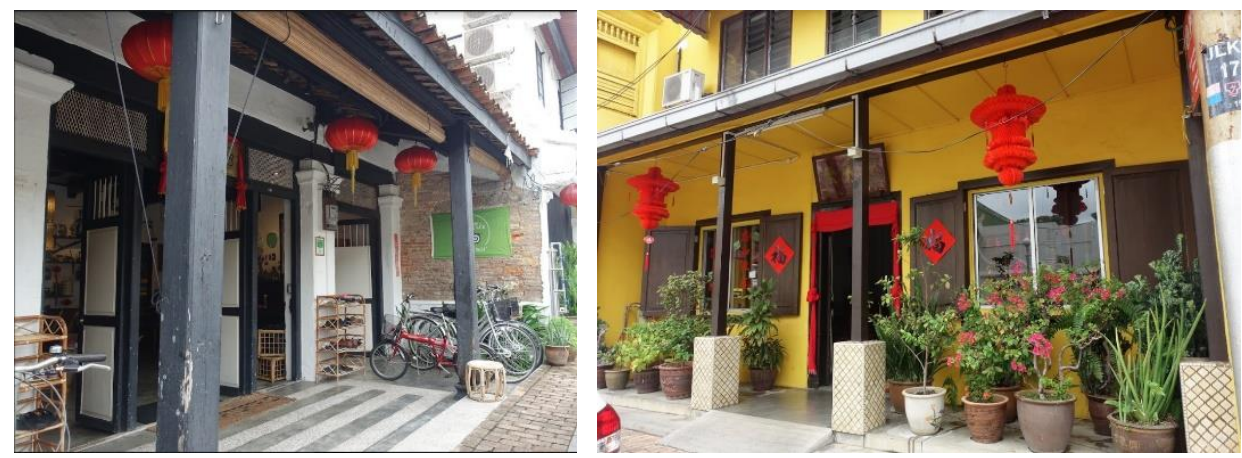

Figure 4: Buildings that have been converted into traveller's lodges while maintaining the original opening character.

Source: Fieldwork, 2016

The opening design of buildings for commercial use should be highly transparent compared to that of residential buildings. Transparency is essential for generating interaction between activities inside and outside of the building and promoting high levels of security and visibility to attract pedestrians (City of Meridian, 2009). In this regard, the 'walking through activity' approach to opening design is more effective compared to the other design approaches, i.e., use of glass and building opening. In other words, the type of building opening design determines the place character (City of Meridian, 2009). The 'walking through activity' design is characteristic of streets of Malaysian urban heritage. This shows that the 'walking through activity' approach to the design of groundlevel building openings contributes towards street character.

Based on our observation, buildings that serve residential functions are associated with 'building opening' designs such as the sliding door grille, folding steel door, folding timber door, timber panel door, and door and window. Archival records show that the folding timber door, timber panel door, and door and window are the original types of opening used, which therefore represent high historical value. According to a Melaka Museums Corporation (PERZIM) official, the types of design approach used has 'changed with the times' due to the process of urban regeneration that has incorporated changes in technology, building function, and surroundings; e.g., changes in building use from commercial to residential and vice versa. This explains our observation of a 
Mohd Hafiz Mohd Nor, Asmidar Alias \& Mohd Faizal Musa

Social Capital in Youth Volunteerism

commercial-to-residential conversion where the occupants maintained the original folding steel doors, as shown in Figure 5 (ii). To maintain privacy, the door was opened only slightly. According to a local who grew up in the area, there were still buildings that maintained their original function and opening, like the residence with timber door and window on both sides as shown in Figure 5 (i).

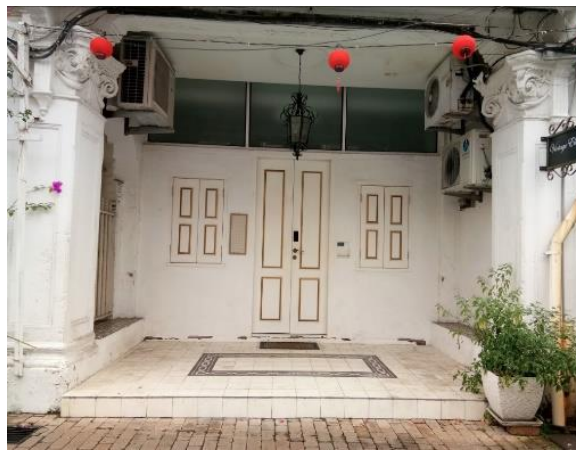

(i)

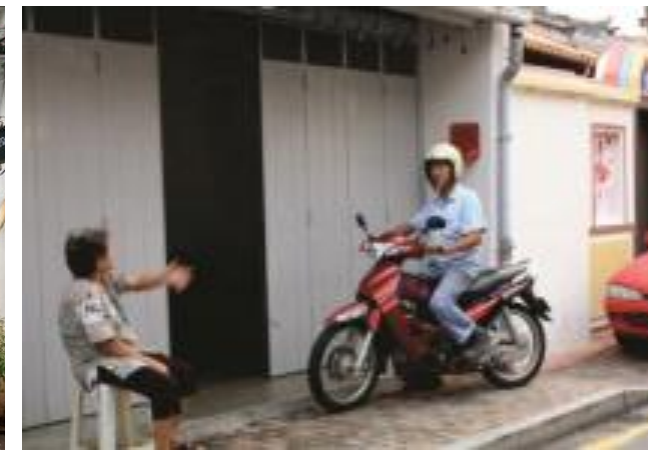

(ii)

Figure 5: (i) A building that maintains its original residential use and opening. (ii) A building that has been changed from commercial to residential use; the occupants keep the opening open only slightly. Source: Fieldwork, 2016

This type of opening approach associated with residential use was mentioned in our interviews.

"There are people living here. I know when the door is open a little and I see their living area." (Respondent 3 )

The above quote reveals that the respondent recognised the activities of occupants' transparencies through the building's small opening. This suggests that the amount of transparencies provided by an opening must correspond with the building use. A building for residential use should be designed with less visibility than one for commercial use.

Francis (1987), and Bently, Alcock, Murrain, McGlynn and Smith (1985) also argue that there must be different levels of transparency for public and private uses. A building's opening design affects the comfort of its occupants (Jacobs, 1993; Jacobs, 2010). Therefore, the opening design of a building with a residential function at the ground level should consider the comfort and privacy of its residents by having less transparency compared to one with a commercial function.

In short, having ground-level building opening design that correspond to building function is essential in contributing towards the traditional street 
character. This study finds that the traditional character should be considered in new and existing street designs in Malaysia through two design approaches:

i. For commercial use, large opening design that creates high transparency, comfort, walkable environment, preferably by the 'walking through activity' approach followed by building opening and glass.

ii. For residential use, the design should consider the privacy of the occupants by not providing high transparency, especially compared to commercial use, via the building opening approach such as door-andwindow.

\section{CONCLUSION}

To conclude, the ground-level building opening design concept that corresponds to building function is vital in enhancing the walkable environments as well as providing comfortable surroundings for the occupants. These environments will strengthen the place character that represents our heritage and local identity. The results of this study could become a guide for architects, landscape architects, urban designers, and planners in designing new or existing streets with diverse functions and ground-level opening designs.

\section{ACKNOWLEDGEMENT}

The authors would like to express their sincere gratitude to Universiti Kebangsaan Malaysia (UKM) and Ministry of Higher Education, Malaysia for funding this study through research grant FRGS/1/2015/SSI11/UKM/02/2.

\section{REFERENCES}

Alexander, C. (1977). A pattern language: Towns-building's-construction. New York: Oxford University Press.

Afsar, B., Mohd Yazid, M. Y., \& Mohd Johari, M., Y. (2015). Assessing essential facilities for daily walking in a tropical campus. Journal of Advances in Environmental Biology, 9(4), 76-78.

Bently, I., Alcock, A., Murrain, P., McGlynn, S., \& Smith, G. (1985). Responsive environment: A manual for designers. London: The Architectural Press.

City of Meridian. (2009). City of Meridian design manual. (n.p.): Author.

de Vaus, D. A. (2003). Surveys in social research. New South Wales: George Allen \& Unwin.

Clark, A. F., Scott, D. M., \& Yiannakoulias, N. (2013). Examining the relationship between active travel, weather, and the built environment: a multilevel approach using a GPS-enhanced dataset. Transportation, 41, 325- 338.

Francis, M. (1987). The making of democratic streets. Firenze: Firenze University Press. Gehl, J. (2010). Cities for people. London: Island Press.

Gehl, J., \& Gemzøe, L. (2001, February). Winning back the cities - The european experience. In Australia: Walking the 21st Century. February 20-22, 2001. Perth, Western Australia.

Gehl, J., Kaefer, L. J., \& Reigstad, S. (2006). Close encounters with buildings. Urban 
Mohd Hafiz Mohd Nor, Asmidar Alias \& Mohd Faizal Musa

Social Capital in Youth Volunteerism

Design International, 29-47.

Handy, S., Xinyu, C., \& Mokhtarian, P. L. (2005). Correlation or causality between the built environment and travel behavior: Evidence from Northern California Transportation Research Part D: Transport and Environment, 10(6), 427-444.

Harun, N. Z., \& Nashar, A. (2016). Developing a framework for streetscape design to promote walkability in Malaysian campus. Advance Science Letter, 23(4), 27612765.

Jaafar, N. H., Abdul Rahim, A., Abd Samad, N. A., \& Che Rahim, C. R.. (2017). Sidewalk accessibility at Melaka's traditional street for people with disabilities (PwDs) Planning Malaysia, 15(1), 389-396.

Jacobs, A. (1993). The great streets. United States of America: The MIT Press.

Jacobs, A. (2010). The importance of streets. In H. C. Kiang, L. B. Liang, \& H. Limin (Eds.), On Asian streets and public space (pp. 159-169). Singapore: Ridge Books.

Litman, T. (2014). Economic value of walkability. World Transport Policy and Practice, $10(1), 5-14$.

Maleki, M. Z., Zain, M. F. M., \& Ismail, A. (2012). Variables communalities and dependence to factors of street system, density, and mixed land use in sustainable site design. Sustainable Cities and Society, 3(1), 46-53.

Miyakoda, A. (2004). A pedestrian friendly environment for downtown Baton Rouge (Master's thesis). Kobe Design University, Japan.

Jones, P., \& Boujenko, N. (2008). Creating more people-friendly urban streets through "link and place". Street Planning And Design, 32(1), 14-25.

Jones, P., \& Boujenko, N. (2011). Street planning and design using "link" and "place". Journeys, (May), 7-15.

Rahman, N. A., Shamsuddin, S., \& Ghani, I. (2014). What makes people use the street? Towards a liveable urban environment in Kuala Lumpur City Centre . Procedia Social and Behavioral Sciences, 170, 624-632.

Sallis, J. F., Frank, L. D., Saelens, B. E., \& Kraft, M. K. (2004). Active transportation and physical activity: opportunities for collaboration on transportation and public health. Transportation Research Part A, 38(4), 249-268.

Shamsuddin, S., Sulaiman, A. B., Ja'afar, N. H., \& Noor, M. M. (2004). Kriteria kejayaan jalan membeli-belah tradisional di Malaysia: Kajian kes Kuala Lumpur. Skudai: Universiti Teknologi Malaysia.

Shamsuddin, S., \& Ujang, N. (2008). Making places: Tthe role of attachment in creating the sense of place for traditional streets in Malaysia. Habitat International, 32, 399-409.

Speck, J. (2012). Walkable city: How downtown can save America. One step at a time. New York: Farrar, Straus and Giroux.

Yap, Y. C., Usman, I., Tahir, M., \& Abidin, I. S. Z. (2010). Assessment of Perbadanan Putrajaya office ground based on urban open space design guideline. Sel. Topics in Energy, Environment, Sustainable Development and Landscaping - 6th WSEAS Int. Conf. on Energy, Environment, Ecosystems and Sustainable Development.

Zakariya, K., Mansor, M., \& Harun, N. Z. (2015) Mapping: A speculative and creative design tool. Creative Space Journal, 3,1-12

Received: $1^{\text {st }}$ June 2018. Accepted: $1^{\text {st }}$ December 2018 